African Crop Science Journal by African Crop Science Society is licensed under a Creative Commons Attribution 3.0 Uganda License. Based on a work at www.ajol.info/ and www.bioline.org.br/cs DOI: https://dx.doi.org/10.4314/acsj.v28i3.2

\title{
EFFECT OF PLANT GROWTH-PROMOTING RHIZOBACTERIA AND GIBBERELLIC ACID ON SALT STRESS TOLERANCE IN TOMATO GENOTYPES
}

\author{
A.M. ESAN, C.O. OLAIYA, L.O. ANIFOWOSE, I.O. LANA, T.O. OMOLEKAN ${ }^{1}$, \\ O. FAGBAMI ${ }^{2}$ and H.R.Y. ADEYEMI ${ }^{3}$ \\ Department of Biochemistry, University of Ibadan, Ibadan, Oyo State, Nigeria \\ ${ }^{1}$ Biochemistry Department, Bowen University Iwo, Osun State, Nigeria \\ ${ }^{2}$ Department of Agronomy, Faculty of Agricultural Sciences, University of Ibadan, Ibadan, \\ Oyo State, Nigeria \\ ${ }^{3}$ Department of Biochemistry, Federal University of Minna, Niger State, Nigeria \\ Corresponding author: cooolaiya@yahoo.com; adexphotocopa@yahoo.com
}

(Received 13 January 2020; accepted 29 June 2020)

\begin{abstract}
Salinity stress is a limiting factor that affects attainment of optimal yield of many vegetable crops at various growth stages in many arid and semi-arid parts of sub-Saharan Africa. The objective of this study was to explore salt tolerance of tomato (Solanum lycopersicum L.) genotypes under the influence of gibberellic acid ( $\left.\mathrm{GA}_{3}\right)$ and Bacillus subtilis under screen house conditions. Tomato seeds were pre-soaked with $0,0.4,0.5$ or $0.6 \mathrm{mM}$ concentrations of $\mathrm{GA}_{3}$ and control in distilled water, respectively; for $12 \mathrm{hr}$ at room temperature. The seeds were germinated in a screen house in $10 \mathrm{~kg}$ of soil contained 0,100 , or $200 \mathrm{mM} \mathrm{NaCl}$ treatment in polyethene bags. After two weeks of seed germination, the seedlings were inoculated with $B$. subtilis with the exception of controls. Results revealed that the single or combined treatments of $\mathrm{GA}_{3}$ (at different concentrations) and Bacillus subtilis significantly $(\mathrm{P}<0.05)$ increased photosynthetic pigments, and enhanced the concentrations of potassium, calcium, magnesium and phosphorus ions in the salt-stressed tomato. Both tomato genotypes showed low concentrations of sodium ions at all levels of gibberellic acid with Bacillus subtilis Also, there were significant $(\mathrm{P}<0.05)$ increases in the compatible solutes, antioxidant enzymes activity and antioxidant potential of salt-stressed tomato genotypes, in the combined treatments of $\mathrm{GA}_{3}$ and Bacillus subtilis. Tomato genotypes treated with $\mathrm{GA}_{3}$ and Bacillus subtilis, showed greater salt-tolerance even at high levels of salinity, than single treatment of either $\mathrm{GA}_{3}$ or Bacillus subtilis. Based on these findings, the genotypes are suitable for future breeding programmes to achieve optimal crop yield in saline conditions.
\end{abstract}

Key Words: Antioxidant enzymes, Bacillus subtilis, Gibberellic acid, Solanum lycopersicum 
Le stress de salinité est un facteur limitant qui affecte la réalisation du rendement optimal de nombreuses cultures potagères dans de nombreuses régions arides et semi-arides de l'Afrique sub-saharienne. L'objectif de cette étude était d'explorer la tolérance au sel des génotypes de tomate (Solanum lycopersicum L.) sous l'influence de l'acide gibbérellique $\left(\mathrm{GA}_{3}\right)$ et de Bacillus subtilis. Les graines de tomate ont été préalablement trempées avec des concentrations de $\mathrm{GA}_{3}$ de 0, 0,4, 0,5 ou 0,6 mM et du contrôle dans de l'eau distillée, respectivement; pendant 12 heures à température ambiante. Les graines ont germé dans un abri grillagé dans $10 \mathrm{~kg}$ de sol contenant 0,100 ou $200 \mathrm{mM}$ de traitement au $\mathrm{NaCl}$ dans des sacs en polyéthylène. Après deux semaines de germination des graines, les plants ont été inoculés avec B. subtilis. Les résultats ont révélé que des traitements uniques ou combinés de $\mathrm{GA}_{3}$ (à différentes concentrations) et de Bacillus subtilis $(\mathrm{P}<0,05)$ augmentaient considérablement les pigments photosynthétiques et augmentaient les concentrations d'ions potassium, calcium, magnésium et phosphore dans la tomate stressée par le sel. Les deux génotypes de tomates ont montré de faibles concentrations d'ions sodium à tous les niveaux d'acide gibbérellique avec Bacillus subtilis. En outre, il y a eu des augmentations significatives $(\mathrm{P}<0,05)$ des solutés compatibles, de l'activité des enzymes antioxydantes et du potentiel antioxydant des génotypes de tomates stressés par le sel, dans les traitements combinés de $\mathrm{GA}_{3}$ et de Bacillus subtilis. Les génotypes de tomates traités avec $\mathrm{GA}_{3}$ et Bacillus subtilis ont montré une plus grande tolérance au sel même à des niveaux élevés de salinité. Sur la base de ces résultats, les génotypes conviennent aux futurs programmes de sélection pour obtenir un rendement optimal des cultures dans des conditions salines.

Mots Clés: Enzymes antioxydantes, Bacillus subtilis, l'acide gibbérellique, Solanum lycopersicum

\section{INTRODUCTION}

Tomato (Solanum lycopersicon L.) is among the most important vegetable crops worldwide; with global production estimated at 200 million metric tones, with India and China as the leading producers (FOASAT, 2019). Tomato is rich in minerals, vitamins and lycopene; and is consumed raw or in processed forms. Lycopene, a major antioxidant in tomato prevents neurodegenerative diseases, diabetes and cancer. It also helps to lower the incidence of Ischemic heart disease (Mahdi et al., 2011). The studies of Katerji et al. (2003) and Magan et al. (2008) have shown the sensitivity of a tomato plant to salinity stress; with major reductions traced particularly in the Mediterranean climatic conditions. Previous reports have demonstrated disastrous salinity stress effects on tomato production, manifested through mechanisms such as nutrient imbalance (Al-Karaki, 2000), ethylene explosion (Mayak et al., 2004), increased levels of $\mathrm{Na}^{+}$and $\mathrm{Cl}$ ions (Fan et al., 2012), and inhibition of photosynthetic potential (Dernetriou et al., 2007). Due to sea level rise, as a result of global climate change, as well as the decreasing availability of high quality irrigation water, salinity is of paramount concern to tomato growers world-wide. Therefore, strategies to improve tomato salt tolerance are increasingly imperative. Several reports have shown that exogenous application of phytohormones induces plant tolerance to various stresses (Pedranzani et al., 2003). Application of gibberellic acid $\left(\mathrm{GA}_{3}\right)$ to Arabidopsis seeds, for instance improved stress tolerance, reportedly through induction of salicylic acid (Alonso-Ramírez et al., 2009). Chakraborti and Mukherji (2003) and Turan et al. (2014) showed that $\mathrm{GA}_{3}$ improves germination and seedling growth of the saltstressed plants.

On the other hand, rhizospheric microorganisms of various plants have the ability to synthesize and release secondary 
metabolites, like phytohormones under stress conditions (Egamberdieva, 2012). Among these microbes, Bacillus subtilis spp. are the major rhizobacteria involved in salt tolerance of plants. Saleh et al. (2005) observed inoculated $B$. subtilis on salt-stressed artichoke plants, which showed a reduction of the negative effects of salinity, and yet increased its productivity. The objective of this study was to explore the effects of giberalic acid $\left(\mathrm{GA}_{3}\right)$ and $B$. subtilis on some biochemical and nutritional constituents of salt-stressed tomato.

\section{MATERIALS AND METHODS}

A screen house experiment was conducted in 2019 (April - August) at the Department of Biochemistry, University of Ibadan, Nigeria. Conditions in the screen house were viz. on average $27{ }^{\circ} \mathrm{C}$ during the day and $25{ }^{\circ} \mathrm{C}$ at night with relative humidity of $50 \%$.

Plant materials. Tomato genotypes used in this study were BF1 and UC82B, which are genotypes widely used in Nigeria as a breeding lines, but with unknown ability to tolerate salinity stress. Seeds for the two genotypes were purchased from the Genetic Resources Laboratory unit at National Horticultural Research Institute, Ibadan, Nigeria.

Treatments and design. Treatments includded two tomato genotypes (BF1 and UC82B), gibberellic acid ( $\left.\mathrm{GA}_{3}\right)$ administered at $0.4,0.5$ or $0.6 \mathrm{mM}$ concentrations; inoculation with $B$. subtilis and under either 0, $100200 \mathrm{mM} \mathrm{NaCl}$ solution. Both $\mathrm{GA}_{3}$ and $B$. subtilis were obtained from the Institute of Agricultural Research and Training, Ibadan, Nigeria and Agronomy Department, University of Ibadan, Nigeria, respectively. Gibberellic acid concentrations were used to pre-soak the seeds. Seeds of each genotype were sown in $10 \mathrm{~kg}$ polyethene bags of soil with analytical properties presented in Table 1.

Seeds were sown in soil that had been treated with a solution of $\mathrm{NaCl}$ based on allotted salinity concentration, in the factorial experiment and was laid out in a completely randomised designed, and treatments replicated three times.

After seed germination, three seedlings per pot were wet with equal volume of water thrice in a week until soil water attained field capacity. After 45 days of growth, all experimental plant leaves were harvested, air-dried for three weeks at room temperature and ground to powder using a mortar and a pestle before the biochemical assay.

Bacillus subtilis cell culture. Bacillus subtilis was isolated from the rhizosphere soil of healthy tomato plants, at the Agronomy Department, University of Ibadan; and cultured on nutrient agar at the Pharmaceutical Microbiology Department, University of Ibadan, Nigeria. The culture was centrifuged at $6200 \mathrm{rpm}$ for $10 \mathrm{~min}$. at $4{ }^{\circ} \mathrm{C}$. Distilled water was used to wash the pellets obtained and then re-suspended in sterilised distilled water to an optical density of 0.8 at $600 \mathrm{~nm}$ (approximate cell density of $\left.1 \times 10^{8} \mathrm{CFUmL}^{-1}\right)$. Two weeks after germination, each seedling was inoculated with $30 \mathrm{~mL}$ of cell suspensions of $1 \times 10^{8}$ $\mathrm{CFU} \mathrm{mL} \mathrm{mL}^{-1}$.

Photosynthetic pigments estimation. The Lichtenthaler and Wellburn (1983) method was applied for the photosynthetic pigments assay of the tomato leaves. Approximately $250 \mathrm{mg}$

TABLE 1. Analytical properties of the soil used

\begin{tabular}{ll}
\hline $\mathrm{pH}$ & 7.10 \\
Exch. acidity $\left(\mathrm{cmol} . \mathrm{kg}^{-1}\right)$ & 0.34 \\
Soil texture & Silt, sandy clay \\
Organic carbon $(\%)$ & 4.732 \\
$\mathrm{~N}(\%)$ & 0.25 \\
Avail. $\left.\mathrm{P}(\mathrm{mg} \mathrm{kg})^{-1}\right)$ & 2.00 \\
Exchangeable K$\left(\mathrm{mol} . \mathrm{kg}^{-1}\right)$ & 1.33 \\
$\mathrm{Na}^{+}\left(\mathrm{cmol} . \mathrm{kg}^{-1}\right)$ & 0.89 \\
$\mathrm{Ca}^{2+}\left(\mathrm{cmol} . \mathrm{kg}^{-1}\right)$ & 45.65 \\
$\mathrm{Mg}^{2+}\left(\mathrm{cmol} . \mathrm{kg}^{-1}\right)$ & 13.34 \\
\hline
\end{tabular}


of tomato fresh leaves was homogenised with $85 \%$ acetone for about $5 \mathrm{~min}$. The sample was mixed using a magnetic stirrer; centrifuged and the absorbance taken at 663,646 , and $470 \mathrm{~nm}$. The concentrations of the pigments were estimated and expressed as $\mathrm{mg}^{-1}$ fresh weight.

Extraction protocol for mineral elements. The samples were digested in an oven at 600 ${ }^{\circ} \mathrm{C}$ for $4 \mathrm{hr}$, the ashes and the crucibles were previously decontaminated with a solution of $10 \%$ nitric acid for a night, and rinsed in the distilled water. Then, $10 \mathrm{~mL}$ of $5 \%$ nitric acid was added to the sample, and this mixture was heated until complete dissolution of the ash. This was filtered and the filtrate put into 25 $\mathrm{mL}$ volumetric flask, and then the volume made up to the required level using distilled water.

Cationic contents. The calcium, magnesium and potassium ion concentrations were determined in the samples according to AOAC (2005) method, using an atomic absorption spectrophotometer flame (BULKS SCIENTIFIC ${ }^{\circledR}$ model AA 240). The concentrations of $\mathrm{Na}^{+}$in the samples were determined by Flame Photometry according to the AOAC (2005) method. Total phosphorus content was determined as described by the spectrophotometry method.

Free proline determination. Proline concentration was estimated in the leaf tissues according to the method described by Bates et al. (1973). Proline was used as a standard (0-50 ìg $\left.\mathrm{mL}^{-1}\right)$, and the reading of proline concentration was taken at $520 \mathrm{~nm}$.

Reducing sugar determination. The method of El-Shihaby et al. (2002) was used to determine the reducing sugar concentration in the tomato plant samples. Briefly, $0.5 \mathrm{~g}$ of dried powder of tomato was extracted by using $80 \%$ ethanol $(10 \mathrm{~mL})$ at $50{ }^{\circ} \mathrm{C}$, and a reaction was set up at about 15-30 min. of the extraction.
Then, $1 \mathrm{~mL}$ of the extracted solution was estimated at $530 \mathrm{~nm}$ using UV/VIS Spectrophotometer. Reducing sugar concentration was expressed as $\mathrm{mg} \mathrm{g}^{-1}$ on dry weight. The glucose was applied as a standard.

Total soluble protein determination. The spectrophotometric technique described by Desingh and Kanagaraj (2007) was used to determine soluble proteins concentration in the plant samples, using Folin-Ciocalteau reagent. About $5 \mathrm{~mL}$ of $10 \%$ trichloroacetic acid was mixed with $0.5 \mathrm{~g}$ of dry leaf powdered sample. The mixture was centrifuged at $2000 \mathrm{rpm}$ for $10 \mathrm{~min}$. Then, about $5 \mathrm{~mL}$ of the supernatant was added to $0.1 \mathrm{M} \mathrm{NaOH}(5 \mathrm{~mL})$, followed by the addition of $8 \mathrm{~mL}$ Biuret reagent. The standard used was BSA (Bovine Serum Albumin). The standard and the sample dilutions were incubated for $30 \mathrm{~min}$ at $25{ }^{\circ} \mathrm{C}$ before the reading was taken at $530 \mathrm{~nm}$.

Enzyme extractions and assays. The Tejera et al. (2004) method was applied to prepare crude enzyme extract. A $1 \mathrm{~g}$ of plant sample was soaked in a buffer solution of potassium phosphate (0.1 M, pH 6) with $0.5 \mathrm{mM}$ EDTA. The sample extract was centrifuged at 15000 rpm for $20 \mathrm{~min}$. The enzymes content of the supernatant was then determined.

Superoxide dismutase assay. Superoxide dismutase activity was assayed using the procedure described by Kumar et al. (2012) (. A $1 \mathrm{~mL}$ of sample was taken at 25 to $500 \mathrm{ig}$ $\mathrm{mL}^{-1}$ concentrations and mixed with $0.5 \mathrm{~mL}$ of buffer solution of potassium phosphate (50 $\mathrm{mM}, \mathrm{pH} 7.6$ ) with $0.1 \mathrm{~mL}$ of nitro bluetetrazolium (NBT) $(0.5 \mathrm{mM})$ and $0.3 \mathrm{~mL}$ of riboflavin $(50 \mathrm{mM})$. A fluorescent lamp was used to initiate the reaction, following incubation for $20 \mathrm{~min}$ at $25^{\circ} \mathrm{C}$. The activity of superoxide dismutase was measured at 560 $\mathrm{nm}$ using UV/VIS Spectrophotometer. The standard used was ascorbic acid $(0.1 \mathrm{mg} / \mathrm{ml})$. The enzyme activity was expressed as Units $\mathrm{mg}^{-1}$ protein. 
Ascorbate peroxidase assay. Ascorbate peroxidase activity was estimated using the method outlined by Yoshimura et al. (2000). The mixture of the reaction contained a buffer solution of potassium phosphate $(50 \mathrm{mM}, \mathrm{pH}$ 7.0) with $0.1 \mathrm{mM}$ of hydrogen peroxide, 0.5 $\mathrm{mM}$ ascorbic acid and $200 \mu \mathrm{L}$ of enzyme extract. The mixture was incubated for $5 \mathrm{~min}$ at $25{ }^{\circ} \mathrm{C}$. The activity of ascorbate peroxidase was measured at $550 \mathrm{~nm}$ using UV/VIS Spectrophotometer. The enzyme activity was expressed as units $\mathrm{mg}^{-1}$ protein.

Polyphenol oxidase assay. The Oktay et al. (1995) method was used to assay for polyphenol oxidase activity with slight modifications. The mixture of the reaction contained buffer solution of $0.1 \mathrm{M}$ potassium phosphate at $\mathrm{pH} 6.0$ with enzyme extract $(0.5$ $\mathrm{mL})$ and $0.1 \mathrm{M}$ catechol $(1.0 \mathrm{~mL})$. The reaction medium was incubated at $25^{\circ} \mathrm{C}$ for 5 min. After which, $1 \mathrm{~mL}$ of $2.5 \mathrm{~N} \mathrm{H}_{2} \mathrm{SO}_{4}$ was added to stop the reaction. The reading was taken at $495 \mathrm{~nm}$ using UV/VIS Spectrophotometer.

Total flavonoids determination. The Park et al. (2008) method was applied to determine the total flavonoid concentration in the sample. The mixture of the reaction contained $0.15 \mathrm{~mL}$ of $0.3 \mathrm{M}$ aluminum chloride $\left(\mathrm{AlCl}_{3}\right), 0.15 \mathrm{~mL}$ of $0.5 \mathrm{M}$ sodium nitrite $\left(\mathrm{NaNO}_{2}\right), 3.4 \mathrm{~mL}$ of $30 \%$ methanol, and $0.3 \mathrm{~mL}$ of the sample extract. The addition of $1 \mathrm{M}$ sodium hydroxide $(1 \mathrm{~mL})$ was done after $5 \mathrm{~min}$. Incubation was donefor about half an hour at $25^{\circ} \mathrm{C}$. Quercetin served as the standard by using its standard curve for determining the flavonoids concentration. Then, the reading was taken at $510 \mathrm{~nm}$ using UV/VIS Spectrophotometer.

Total phenolic determination. The spectrophotometric method was employed to determine total phenolic content in the sample (Kim et al., 2003). Approximately $1 \mathrm{~mL}$ of Folin-ciocalteu's phenol reagent was added to $1 \mathrm{~mL}$ of the sample. A $10 \mathrm{~mL}$ of $7 \% \mathrm{Na}_{2} \mathrm{CO}_{3}$ solution was added to the mixture after $5 \mathrm{~min}$. and thoroughly mixed with distilled water (13 $\mathrm{ml}$ ) using a magnetic stirrer. The reaction was stored for $90 \mathrm{~min}$ at $25{ }^{\circ} \mathrm{C}$ in the dark. The reading was then taken at $750 \mathrm{~nm}$ using UV/ VIS Spectrophotometer. Gallic acid was used as the standard by using its standard curve for determining the phenolic concentration.

Statistical analysis. The data collected were subjected to three-way analysis of variance (ANOVA) using the Statistical Package for the Social Sciences (SPSS). Sample means were compared using Tukey-Kramer multiple comparison procedure at $\mathrm{P}<0.05$.

\section{RESULTS}

Photosynthetic pigments content. Tables 2 and 3 show that single treatment of tomato seedlings with $B$. subtilis and gibberellic acid induced a rise in the concentrations of tissue chlorophyll $\mathrm{a}$ and $\mathrm{b}$ in all the $\mathrm{NaCl}$-treated plants. Under the combined effects of gibberellic acid and Bacillus subtilis, tomato genotype UC82B responded more positively with increase contents of photosynthetic pigments than the genotype BF1.

Minerals concentration. Tables $4(a, b)$ and $5(a, b)$ show that the single treatment of $B$. subtilis or $\mathrm{GA}_{3}$ at different concentrations, respectively; as well as the combined treatments of B. subtilis at different concentrations of $\mathrm{GA}_{3}$, enhanced the levels of potassium, calcium, magnesium and phosphorus ions in the two genotypes of saltstressed tomato plants. Also, these were more significant at 0.5 and $0.6 \mathrm{mM}$ concentrations of gibberellic acid combined with B. subtilis in the BF1 and UC82B genotypes than in the normal control and the two negative controls (100 and $200 \mathrm{mM}$ of sodium chloride) groups. The individual concentration of gibberellic acid or B. subtilis, as well as the combined treatments of B. subtilis with different concentrations of gibberellic acid significantly reduced sodium ion concentration in the saltstressed tomato plant of the two genotypes 
TABLE 2. Gibberellic acid and Bacillus subtilis effects on photosynthetic pigments of salt-stressed tomato plant BF1 genotype

\begin{tabular}{|c|c|c|c|c|}
\hline Treatments & $\mathrm{NaCl}(\mathrm{mM})$ & $\begin{array}{l}\text { Chlorophyll a } \\
\left(\mathrm{mg} \mathrm{g}^{-1} \mathrm{fw}\right)\end{array}$ & $\begin{array}{l}\text { Chlorophyll b } \\
\left(\mathrm{mg} \mathrm{g}^{-1} \mathrm{fw}\right)\end{array}$ & $\begin{array}{l}\text { Carotenoids } \\
\left(\mathrm{mg} \mathrm{g}^{-1} \mathrm{fw}\right)\end{array}$ \\
\hline \multirow[t]{3}{*}{$0 \mathrm{mM}$} & 0 & $1.18 \pm 0.28$ & $1.10 \pm 0.24$ & $2.53 \pm 0.42$ \\
\hline & 100 & $0.14 \pm 0.16$ & $1.61 \pm 0.04$ & $0.68 \pm 0.56$ \\
\hline & 200 & $0.35 \pm 0.01^{*}$ & $0.96 \pm 0.02 *$ & $0.54 \pm 0.14$ \\
\hline \multirow[t]{3}{*}{$\mathrm{GA}_{3}(0.4 \mathrm{mM})$} & 0 & $1.53 \pm 0.33$ & $1.59 \pm 0.28$ & $3.34 \pm 0.33$ \\
\hline & 100 & $2.38 \pm 0.26 * *$ & $1.80 \pm 0.22$ & $2.35 \pm 0.04$ \\
\hline & 200 & $0.40 \pm 0.08$ & $1.15 \pm 0.16$ & $1.40 \pm 0.01$ \\
\hline \multirow[t]{3}{*}{$\mathrm{GA}_{3}(0.5 \mathrm{mM})$} & 0 & $1.21 \pm 0.14$ & $1.91 \pm 0.25$ & $3.68 \pm 0.32$ \\
\hline & 100 & $1.35 \pm 0.28$ & $1.15 \pm 0.16$ & $3.50 \pm 0.25$ \\
\hline & 200 & $3.76 \pm 0.02 * * *$ & $0.76 \pm 0.02$ & $2.13 \pm 0.01$ \\
\hline \multirow[t]{3}{*}{$\mathrm{GA}_{3}(0.6 \mathrm{mM})$} & 0 & $1.70 \pm 0.02$ & $1.89 \pm 0.01$ & $3.69 \pm 0.02$ \\
\hline & 100 & $1.16 \pm 0.28$ & $1.23 \pm 0.08$ & $3.22 \pm 0.16$ \\
\hline & 200 & $1.79 \pm 0.31$ & $0.99 \pm 0.27$ & $2.13 \pm 0.28$ \\
\hline \multirow[t]{3}{*}{ B. subtilis } & 0 & $1.15 \pm 0.01$ & $1.14 \pm 0.01$ & $3.35 \pm 0.01$ \\
\hline & 100 & $3.98 \pm 0.02 * *$ & $1.20 \pm 0.02$ & $2.98 \pm 0.01$ \\
\hline & 200 & $3.69 \pm 0.04 * * *$ & $0.77 \pm 0.04$ & $2.40 \pm 0.04$ \\
\hline \multirow[t]{3}{*}{$\mathrm{GA}_{3}(0.4 \mathrm{mM})+B$. subtilis } & 0 & $1.54 \pm 0.02$ & $3.71 \pm 0.02 *$ & $5.89 \pm 0.01 *$ \\
\hline & 100 & $3.10 \pm 0.21 * *$ & $1.55 \pm 0.16$ & $3.75 \pm 0.13$ \\
\hline & 200 & $3.36 \pm 0.26 * * *$ & $0.33 \pm 0.22$ & $2.58 \pm 0.22$ \\
\hline \multirow[t]{3}{*}{$\mathrm{GA}_{3}(0.5 \mathrm{mM})+B$. subtilis } & 0 & $1.23 \pm 0.16$ & $1.13 \pm 0.25$ & $5.90 \pm 0.16 *$ \\
\hline & 100 & $3.59 \pm 0.27 * *$ & $1.00 \pm 0.31$ & $4.28 \pm 0.32 * *$ \\
\hline & 200 & $3.96 \pm 0.22 * * *$ & $0.90 \pm 0.22$ & $3.08 \pm 0.32$ \\
\hline \multirow[t]{3}{*}{$\mathrm{GA}_{3}(0.6 \mathrm{mM})+$ B. subtilis } & 0 & $1.87 \pm 0.04$ & $1.54 \pm 0.04$ & $5.19 \pm 0.05$ \\
\hline & 100 & $1.18 \pm 0.25$ & $1.62 \pm 0.18$ & $4.31 \pm 0.22 * *$ \\
\hline & 200 & $0.10 \pm 0.14$ & $1.18 \pm 0.18$ & $3.30 \pm 0.14$ \\
\hline
\end{tabular}

Data are means $\pm \mathrm{SE}(\mathrm{n}=3) . * * *$ and $* * *$ Significant differences at $\mathrm{P}<0.05$ to the normal control, negative controls at 100 and $200 \mathrm{mM} \mathrm{NaCl}$ respectively determined by Tukey-Kramer multiple range test 
TABLE 3. Gibberellic acid and Bacillus subtilis effects on photosynthetic pigments of salt-stressed tomato plant UC82B genotype

\begin{tabular}{|c|c|c|c|c|}
\hline Treatments & $\mathrm{NaCl}(\mathrm{mM})$ & $\begin{array}{l}\text { Chlorophyll a } \\
\left(\mathrm{mg} \mathrm{g}^{-1} \mathrm{fw}\right)\end{array}$ & $\begin{array}{l}\text { Chlorophyll b } \\
\left(\mathrm{mg} \mathrm{g}^{-1} \mathrm{fw}\right)\end{array}$ & $\begin{array}{l}\text { Carotenoids } \\
\left(\mathrm{mg} \mathrm{g}^{-1} \mathrm{fw}\right)\end{array}$ \\
\hline \multirow[t]{3}{*}{$0 \mathrm{mM}$} & 0 & $1.26 \pm 0.02$ & $1.30 \pm 0.02$ & $1.80 \pm 0.02$ \\
\hline & 100 & $0.34 \pm 0.20$ & $1.65 \pm 0.34$ & $0.06 \pm 0.29$ \\
\hline & 200 & $0.51 \pm 0.34$ & $0.86 \pm 0.67 *$ & $0.05 \pm 0.65$ \\
\hline \multirow[t]{3}{*}{$\mathrm{GA}_{3}(0.4 \mathrm{mM})$} & 0 & $3.26 \pm 0.21$ & $2.25 \pm 0.17$ & $1.50 \pm 0.27$ \\
\hline & 100 & $2.25 \pm 0.02$ & $3.12 \pm 0.02$ & $1.18 \pm 0.02$ \\
\hline & 200 & $1.19 \pm 0.03$ & $3.37 \pm 0.03$ & $0.87 \pm 0.02$ \\
\hline \multirow[t]{3}{*}{$\mathrm{GA}_{3}(0.5 \mathrm{mM})$} & 0 & $3.23 \pm 0.29$ & $3.59 \pm 0.15^{* * *} *$ & $1.41 \pm 0.11$ \\
\hline & 100 & $2.13 \pm 0.34$ & $2.43 \pm 0.33$ & $0.82 \pm 0.27$ \\
\hline & 200 & $1.12 \pm 1.96$ & $1.23 \pm 0.18$ & $0.49 \pm 1.19$ \\
\hline \multirow{3}{*}{$\mathrm{GA}_{3}(0.6 \mathrm{mM})$} & 0 & $3.37 \pm 0.94$ & $2.91 \pm 0.50$ & $1.75 \pm 0.37$ \\
\hline & 100 & $2.11 \pm 0.56$ & $1.31 \pm 0.03$ & $1.12 \pm 0.03$ \\
\hline & 200 & $1.20 \pm 0.11$ & $1.95 \pm 1.62$ & $1.04 \pm 0.20$ \\
\hline \multirow[t]{3}{*}{ B. subtilis } & 0 & $3.20 \pm 0.07$ & $3.43 \pm 0.93$ & $1.49 \pm 0.36$ \\
\hline & 100 & $2.24 \pm 0.56$ & $2.48 \pm 0.56$ & $0.74 \pm 0.75$ \\
\hline & 200 & $1.58 \pm 0.88$ & $1.26 \pm 0.38$ & $0.49 \pm 0.52$ \\
\hline \multirow{3}{*}{$\mathrm{GA}_{3}(0.4 \mathrm{mM})+\mathrm{B}$. subtilis } & 0 & $3.28 \pm 0.12 *$ & $1.55 \pm 0.12$ & $3.54 \pm 0.50$ \\
\hline & 100 & $2.29 \pm 0.75^{* *}$ & $2.95 \pm 0.19$ & $2.96 \pm 0.74 * *$ \\
\hline & 200 & $2.18 \pm 0.24 * * *$ & $1.70 \pm 0.17$ & $2.29 \pm 0.26$ \\
\hline \multirow[t]{3}{*}{$\mathrm{GA}_{3}(0.5 \mathrm{mM})+B$. subtilis } & 0 & $3.50 \pm 0.32 *$ & $1.81 \pm 0.34$ & $3.50 \pm 0.47$ \\
\hline & 100 & $2.21 \pm 0.53 * *$ & $3.26 \pm 0.51 * *$ & $2.43 \pm 0.67 * *$ \\
\hline & 200 & $1.14 \pm 0.03$ & $2.18 \pm 0.03 * * *$ & $1.40 \pm 0.01$ \\
\hline \multirow[t]{3}{*}{$\mathrm{GA}_{3}(0.6 \mathrm{mM})+$ B. subtilis } & 0 & $2.93 \pm 0.32$ & $1.13 \pm 0.34$ & $3.15 \pm 0.24$ \\
\hline & 100 & $1.27 \pm 0.38$ & $2.9 \pm 0.53$ & $2.07 \pm 0.23 * * *$ \\
\hline & 200 & $3.16 \pm 0.20 * * *$ & $3.12 \pm 0.40 * * *$ & $1.56 \pm 0.68$ \\
\hline
\end{tabular}

Data are means $\pm \mathrm{SE}(\mathrm{n}=3) . *, * *$ and $* * *$ Significant differences at $\mathrm{P}<0.05$ to the normal control, negative controls at 100 and $200 \mathrm{mM} \mathrm{NaCl}$ respectively determined by Tukey-Kramer multiple range test 
TABLE 4 A. The gibberellic acid or Bacillus subtilis effect on mineral ( $\mathrm{mg} \mathrm{g}^{-1} \mathrm{dw}$ ) elements of salt-stressed tomato plant BF1 genotype

\begin{tabular}{|c|c|c|c|c|c|c|}
\hline Treatment & $\begin{array}{l}\mathrm{NaCl} \\
(\mathrm{mM})\end{array}$ & $\mathrm{Na}$ & $\mathrm{Mg}$ & $\mathrm{Ca}$ & $\mathrm{K}$ & $\mathrm{P}$ \\
\hline \multirow[t]{3}{*}{$0(\mathrm{mM})$} & 0 & $106.27 \pm 0.33$ & $131.00 \pm 3.70$ & $125.73 \pm 3.45$ & $217.78 \pm 4.10$ & $262.11 \pm 3.59$ \\
\hline & 100 & $211.87 \pm 0.16$ & $105.47 \pm 3.80$ & $105.34 \pm 7.61$ & $133.24 \pm 6.83$ & $181.60 \pm 2.50$ \\
\hline & 200 & $291.51 \pm 0.33$ & $55.66 \pm 5.00 *$ & $82.85 \pm 0.75^{*}$ & $104.20 \pm 3.00 *$ & $103.60 \pm 4.17 *$ \\
\hline \multirow[t]{3}{*}{$\mathrm{GA}_{3}(0.4 \mathrm{mM})$} & 0 & $90.48 \pm 0.26$ & $155.69 \pm 3.71$ & $150.34 \pm 3.52$ & $364.64 \pm 5.52$ & $273.61 \pm 2.00$ \\
\hline & 100 & $117.93 \pm 0.17$ & $132.06 \pm 5.00$ & $133.97 \pm 0.56$ & $290.10 \pm 6.94$ & $232.32 \pm 2.99$ \\
\hline & 200 & $201.76 \pm 0.24 * *$ & $115.39 \pm 0.37$ & $118.26 \pm 0.74$ & $360.20 \pm 5.20$ & $204.33 \pm 2.13$ \\
\hline \multirow[t]{3}{*}{$\mathrm{GA}_{3}(0.5 \mathrm{mM})$} & 0 & $21.08 \pm 0.20$ & $152.48 \pm 1.20$ & $139.22 \pm 7.42$ & $365.70 \pm 4.90$ & $281.69 \pm 4.13$ \\
\hline & 100 & $17.47 \pm 0.20$ & $134.65 \pm 1.20$ & $128.10 \pm 3.89$ & $267.17 \pm 3.49$ & $240.22 \pm 3.38$ \\
\hline & 200 & $22.87 \pm 0.34$ & $111.23 \pm 5.00$ & $114.47 \pm 0.19$ & $277.19 \pm 4.90$ & $209.75 \pm 3.48 * *$ \\
\hline \multirow[t]{3}{*}{$\mathrm{GA}_{3}(0.6 \mathrm{mM})$} & 0 & $20.95 \pm 0.29$ & $155.39 \pm 4.45$ & $147.19 \pm 4.27$ & $367.82 \pm 3.28$ & $279.70 \pm 3.09$ \\
\hline & 100 & $19.16 \pm 0.15$ & $134.62 \pm 3.58$ & $129.22 \pm 0.75$ & $329.85 \pm 5.69$ & $233.75 \pm 2.56$ \\
\hline & 200 & $22.55 \pm 0.11$ & $110.54 \pm 5.00$ & $114.22 \pm 0.75$ & $359.23 \pm 5.60$ & $209.74 \pm 1.91$ \\
\hline \multirow[t]{3}{*}{ B. subtilis } & 0 & $18.08 \pm 0.27$ & $152.98 \pm 5.00$ & $153.99 \pm 3.52$ & $350.20 \pm 6.87$ & $279.05 \pm 4.05$ \\
\hline & 100 & $19.92 \pm 0.33$ & $137.83 \pm 4.45$ & $131.73 \pm 0.19$ & $321.21 \pm 5.47$ & $226.25 \pm 3.25$ \\
\hline & 200 & $22.85 \pm 0.34$ & $109.85 \pm 2.50$ & $116.25 \pm 0.56$ & $309.21 \pm 4.50$ & $206.19 \pm 3.34 * *$ \\
\hline
\end{tabular}

Data are means $\pm \mathrm{SE}(\mathrm{n}=3) . * * *$ and $* * *$ are significant differences at $\mathrm{P}<0.05$ to the normal control and positive control groups $\left(\mathrm{GA}_{3}\right.$ or $B$. subtilis) respectively determined by Tukey-Kramer multiple range test

when compared to the normal control and the two negative controls (100 and $200 \mathrm{mM} \mathrm{NaCl}$ ) groups.

Free proline concentration. As shown in Figure 1, in the two genotypes of tomato (BF1 and UC82B), B. subtilis or gibberellic acid, as well as the combined treatments at different concentrations of gibberellic acid under salinity stress increased proline accumulation in the tomato plant. But the significant increase in proline concentration was observed at 0.5 and $0.4 \mathrm{mM}$ concentrations of gibberellic acid combined with $B$. subtilis in the BF1 or UC82B genotypes, when compared with the normal control and the $\mathrm{NaCl}$-treated groups.

Reducing sugar and soluble protein concentrations. Results showed an increase reducing sugar concentrations in the two genotypes of tomato (BF1 and $\mathrm{UC} 82 \mathrm{~B})$ under single treatment of $B$. subtilis or gibberellic acid, as well as co-treatments at different concentrations of gibberellic acid in the two tomato genotypes (Fig. 2). The increase in the concentrations of reducing sugar was higher at 0.5 and $0.4 \mathrm{mM}$ concentrations of gibberellic acid combined with $B$. subtilis in the BF1 and UC82B genotypes, respectively when compared with the normal control and NaCl-treated groups (Fig. 2). A similar trend was observed for the total soluble protein concentrations in both $\mathrm{BF} 1$ and UC82B genotypes (Fig. 3).

Ascorbate peroxidase activity. Figure 4 shows an increase in the ascorbate peroxidase activity in salt-stressed tomato BF1 and UC82B genotypes in a single treatment of gibberellic acid or B. subtilis. But the steady increase in the ascorbate peroxidase activity was discovered in co-treatments of gibberellic acid and B. subtilis in salt-stressed tomato (BF1 
and UC82B genotypes) plant as compared to the normal and NaCl-treated groups.

Polyphenol oxidase activity. Single treatment of gibberellic acid or B. Subtilis had little or no effect on the polyphenol oxidase activity of salt-stressed tomato (BF1 and UC82B genotypes) plant when compared to the normal control and $\mathrm{NaCl}$-treated groups (Fig. 5). However, co-treatments with gibberellic acid and $B$. subtilis increased the polyphenol oxidase activity in salt-stressed tomato plant BF1 and UC82B genotypes, as compared to the single treatment of gibberellic acid or $B$. subtilis, normal control and $\mathrm{NaCl}$-treated groups.

Superoxide dismutase activity. Figure 6 shows that superoxide dismutase activity was not improved in a single treatment of gibberellic acid or B. subtilis in salt-stressed tomato (BF1 and UC82B genotypes) plant when compared to the normal control and $\mathrm{NaCl}$-treated groups. However, superoxide dismutase activity was significantly increased in the salt-stressed tomato plant BF1 and UC82B genotypes under the combined effects of gibberellic acid and B. subtilis, compared to a single treatment of gibberellic acid or $B$. subtilis, normal control and NaCl-treated groups.

Total flavonoids and phenolic contents. Figure 7 shows that pre-soaked seeds and seedling inoculated with $B$. Subtilis had no significant effect $(\mathrm{P}<0.05)$ on total flavonoids content in salt-stressed tomato (BF1 and UC82B genotypes), when compared with the normal control and $\mathrm{NaCl}$-treated groups. However, total flavonoids content was significantly increased in the control group treated with combined effects of gibberellic acid and B. subtilis at all concentrations of gibberellic acid when compared with the normal and $\mathrm{NaCl}$-treated groups in both genotypes. Figure 8 presented a similar trend for total phenolic contents in both BF1 and UC82B genotypes. 
TABLE 5 A. Gibberellic acid or Bacillus subtilis effect on mineral ( $\mathrm{mg} \mathrm{g}^{-1} \mathrm{dw}$ ) elements of saltstressed tomato plant UC82B genotype

\begin{tabular}{lrccccc}
\hline Treatment & $\begin{array}{c}\mathrm{NaCl} \\
(\mathrm{mM})\end{array}$ & $\mathrm{Na}$ & $\mathrm{Mg}$ & $\mathrm{Ca}$ & $\mathrm{K}$ & $\mathrm{P}$ \\
& & & & & \\
\hline $\mathrm{mM}$ & 0 & $16.34 \pm 0.18$ & $134.65 \pm 1.20$ & $135.73 \pm 3.45$ & $358.77 \pm 3.21$ & $181.78 \pm 1.80$ \\
& 100 & $220.17 \pm 0.22^{*}$ & $106.40 \pm 9.30$ & $115.98 \pm 0.75$ & $236.48 \pm 8.50$ & $126.42 \pm 3.02$ \\
& 200 & $302.6 \pm 0.04^{*}$ & $81.04 \pm 0.50^{*}$ & $86.78 \pm 0.17 *$ & $121.00 \pm 3.70 *$ & $113.05 \pm 7.90$ \\
& & & & & & \\
$\mathrm{GA}_{3}(0.4 \mathrm{mM})$ & 0 & $21.45 \pm 0.04$ & $161.85 \pm 1.92$ & $140.81 \pm 0.11$ & $408.00 \pm 1.19$ & $236.33 \pm 1.80$ \\
& 100 & $117.59 \pm 0.04^{* *}$ & $152.22 \pm 3.71$ & $147.66 \pm 1.62$ & $360.33 \pm 4.40$ & $201.70 \pm 2.17$ \\
& 200 & $121.22 \pm 0.04^{* *}$ & $121.23 \pm 0.52$ & $125.69 \pm 0.20$ & $237.85 \pm 4.94$ & $301.70 \pm 8.90$ \\
$\mathrm{GA}_{3}(0.5 \mathrm{mM})$ & 0 & $42.96 \pm 0.28$ & $165.84 \pm 0.88$ & $160.39 \pm 3.34$ & $402.75 \pm 3.39$ & $244.41 \pm 2.07$ \\
& 100 & $17.88 \pm 0.08^{* *}$ & $157.08 \pm 3.80$ & $149.88 \pm 3.52$ & $368.70 \pm 5.80$ & $212.10 \pm 1.27$ \\
& 200 & $22.13 \pm 0.16$ & $115.08 \pm 3.71$ & $128.98 \pm 0.05$ & $292.55 \pm 4.09 * *$ & $235.56 \pm 4.50$ \\
GA $_{3}(0.6 \mathrm{mM})$ & 0 & $40.50 \pm 0.24$ & $161.65 \pm 0.94$ & $167.19 \pm 3.90$ & $404.00 \pm 4.41$ & $237.39 \pm 2.69$ \\
& 100 & $18.16 \pm 0.28^{* *}$ & $150.98 \pm 5.00$ & $129.22 \pm 0.75$ & $339.20 \pm 4.41$ & $217.20 \pm 3.52$ \\
& 200 & $22.89 \pm 0.16$ & $125.65 \pm 2.98$ & $131.73 \pm 0.19$ & $271.85 \pm 5.76$ & $235.45 \pm 8.90$ \\
& & & & & & \\
B. subtilis & 0 & $18.73 \pm 0.22$ & $156.33 \pm 0.10$ & $163.08 \pm 4.64$ & $407.75 \pm 3.31$ & $226.93 \pm 2.77$ \\
& 100 & $17.20 \pm 0.16$ & $139.78 \pm 3.70$ & $134.24 \pm 0.03$ & $364.15 \pm 4.53$ & $205.21 \pm 2.02$ \\
& 200 & $21.06 \pm 0.22$ & $114.24 \pm 0.30$ & $124.43 \pm 0.56$ & $252.24 \pm 3.30$ & $105.21 \pm 7.80$ \\
\hline & & & & & &
\end{tabular}

Data are means $\pm \mathrm{SE}(\mathrm{n}=3)$. $* * *$ and $* * *$ are significant differences at $\mathrm{P}<0.05$ to the normal control and positive control groups ( $\mathrm{GA}_{3}$ or $B$. subtilis) respectively determined by Tukey-Kramer multiple range test

\section{DISCUSSION}

The higher photosynthetic pigments content of groups treated with $\mathrm{GA}_{3}$ and B. subtilis (Tables 2 and 3) than in the salt-stressed groups may be due to the growth promoting effects of $\mathrm{GA}_{3}$ and or $B$. subtilis, which increases photosynthetic efficiency, and in turn improves plant biomass. Mohamed and Gomaa (2012) observed increases in chlorophyll $a, b$ and carotenoid contents in leaves of saltstressed radish plants, following inoculation with strains of B. subtilis and Pseudomonas fluorescens. Studies of salinity stress in plants have shown its inhibition of photosynthesis and protein synthesis, which in turn serve as barriers to horticultural production (Hashem et al., 2014). It is clear from this study that salinity stress increases the concentrations of tissue sodium, with a reduction in the concentrations of some essential mineral elements $(\mathrm{Mg}, \mathrm{Ca}, \mathrm{K}$, and $\mathrm{P})$ in the tomato genotypes, which in turn leads to nutrient deficiency (Tables 4 and 5). The implication of salinity stress on the nutrient compositions of plant tissues, especially calcium and potassium ion contents have been studied widely, and affirm the detrimental effects of salinity on nutrient availability (Tester, 2003; Hussain et al. 2015). The phosphorus, potassium, calcium, and magnesium ions concentrations were found to be higher than sodium ion in the groups treated with gibberellic acid and B. subtilis in BF1 and UC82B genotypes (Tables 4a, b and 5a, b). This support the observation of Dodd and 
Perez-Alfocea (2012) that plant growthpromoting rhizobacteria (PGPR) could decrease toxic ions acquisition and maintain the intracellular ionic equilibrium, and thus increase nutrients availability in plants.

The lower level of sodium ion observed in the treatments at different concentrations support the growth of tomato by protecting its tissues from toxic effects of salinity stress, and thus ensure ionic homeostasis in the two tomato genotypes. Esan et al. (2017) observed improvement in okra plants under saline conditions, following seeds pre-treatment with indole acetic acid and salicylic acid. Salt stress increased proline concentration in BF1 and UC82B tomato genotypes, which in turn upregulates the enzymes activity and down regulates the catabolising enzymes activity for proline synthesis (Moxley et al., 2011). Accumulation of proline is an indicator of stress tolerance in plants (Parviz and Satyawat, 2008). Results obtained were similar to the one reported by Ahmad et al. (2016), who observed increased proline concentration, which in turn improved the fresh and dry weights of chickpea plants growing under high-salinity conditions by inoculation with Bacillus subtilis.

The increase in reducing sugar content of salt-stressed tomato (BF1 and UC82B genotypes) treated with gibberellic acid and B. subtilis (Fig. 2), is responsible for the osmotic potential, which ensure water uptake in the tissue of salt-stressed tomato. A similar report was published by Amin et al. (2009), who observed increased reducing sugar concentrations in okra under drought stress, which is a signal for water deficiency tolerance, it also reduces water potential to prevent oxidative losses and protein structure maintenance during water shortage. The significant increase in soluble protein content of salt-stressed tomato (BF1 and UC82B genotypes) treated with gibberellic acid and B. subtilis (Fig. 3) may be attributed to the production of some proteins in response to salt stress, which is deducted by gibberellic acid. Metwali et al. (2015) reported a similar 

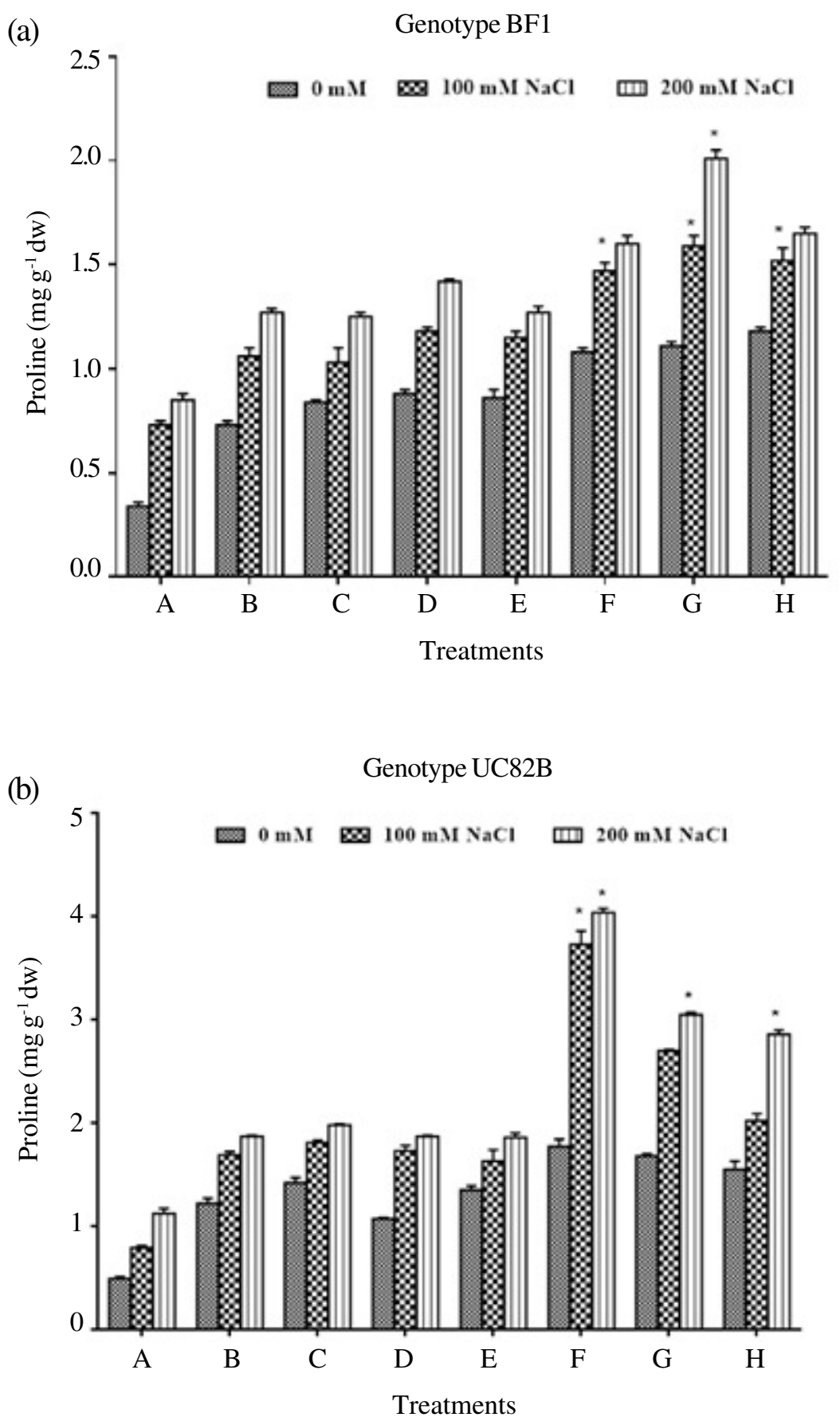

Figure 1. Proline accumulation of salt-stressed tomato genotypes (a) BF1and (b) UC82B under the influence of gibberellic acid and B. subtilis. Values represent means \pm standard error $(\mathrm{n}=3)$. *Significant difference $(\mathrm{P}<0.05)$ to the salt-stressed control and the normal control groups. Where $\mathrm{A}=\mathrm{Controls}$ (Normal control and Negative control groups), B, C, and D = 0.4, 0.5, and 0.6 mM of gibberellic acid respectively, $\mathrm{E}=$ Bacillus subtilis, $\mathrm{F}, \mathrm{G}$, and $\mathrm{H}=0.4,0.5$, and $0.6 \mathrm{mM}$ of gibberellic acid and Bacillus subtilis respectively. 
(a) Genotype BF1

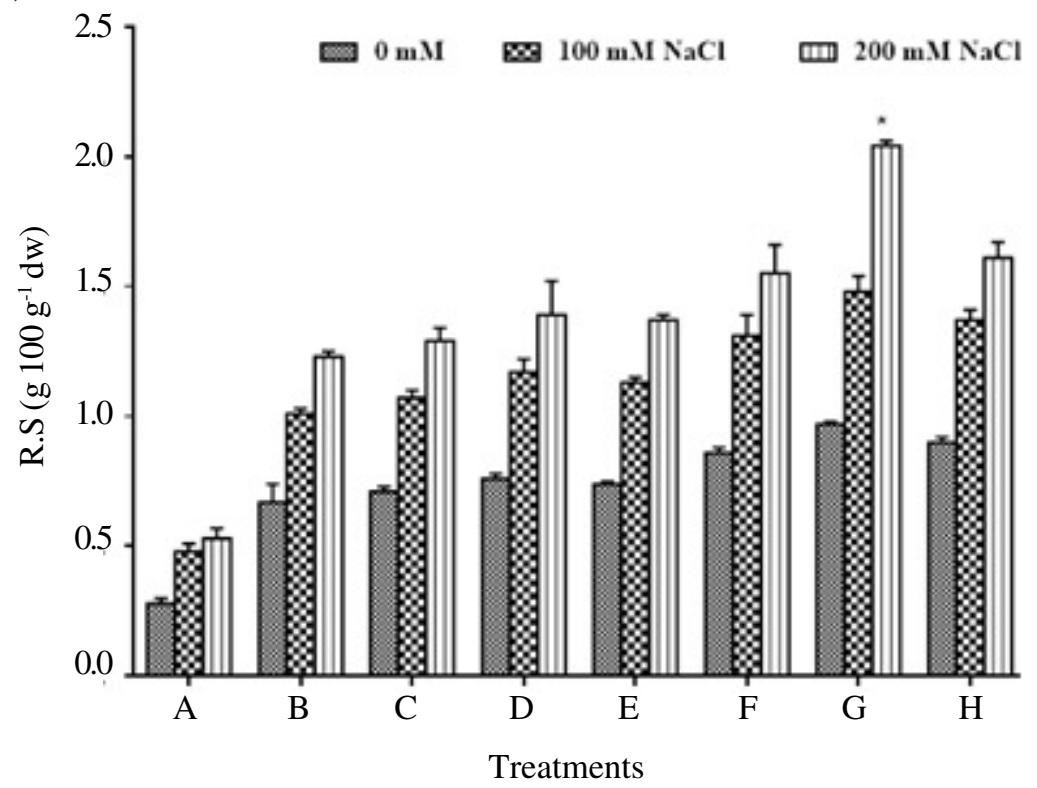

(b) Genotype UC82B

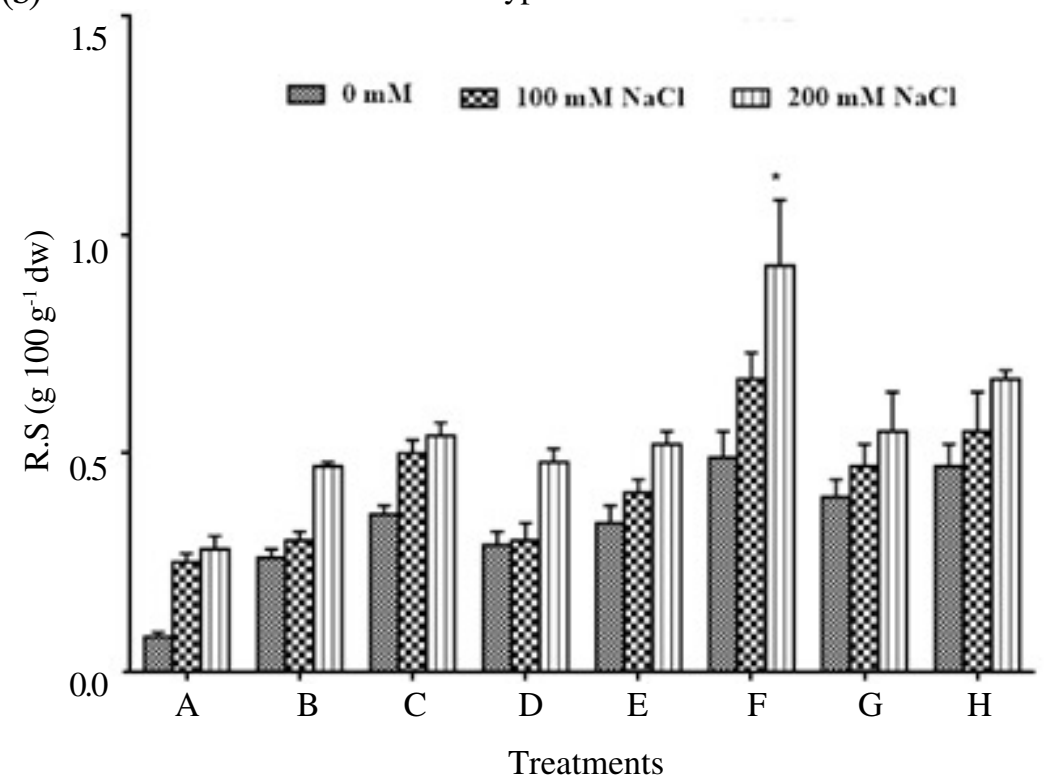

Figure 2. Reducing sugar accumulation of salt-stressed tomato genotypes (a) BF1 and (b) UC82B under the influence of gibberellic acid and B. subtilis. Values represent means \pm standard error $(\mathrm{n}=3)$. $*$ Significant difference $(\mathrm{P}<0.05)$ to the salt-stressed control and the normal control groups. Where A $=$ Controls (Normal control and Negative control groups), B, C, and D =0.4, 0.5, and $0.6 \mathrm{mM}$ of gibberellic acid respectively, $\mathrm{E}=$ Bacillus subtilis, $\mathrm{F}, \mathrm{G}$, and $\mathrm{H}=0.4,0.5$, and $0.6 \mathrm{mM}$ of gibberellic acid and Bacillus subtilis respectively. 

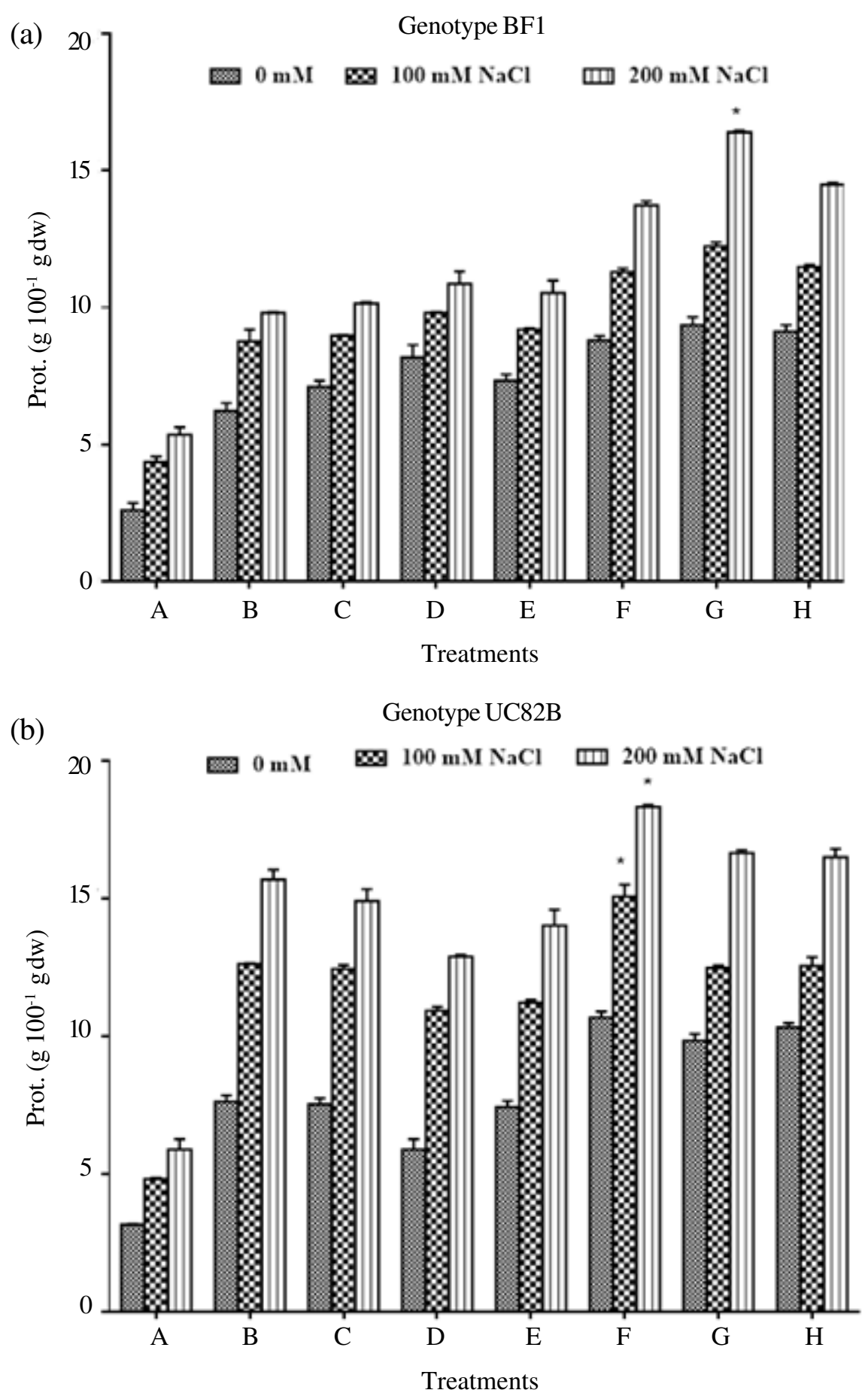

Figure 3. Soluble protein accumulation of salt-stressed tomato genotypes (a) BF1 and (b) UC82B under the influence of gibberellic acid and B. subtilis. Values represent means \pm standard error $(\mathrm{n}=3)$. *Significant difference $(\mathrm{P}<0.05)$ relatives to the salt-stressed control and the normal control groups. Where $\mathrm{A}=$ Controls (Normal control and Negative control groups), B, C, and D = 0.4, 0.5, and $0.6 \mathrm{mM}$ of gibberellic acid respectively, $\mathrm{E}=$ Bacillus subtilis, $\mathrm{F}, \mathrm{G}$, and $\mathrm{H}=0.4,0.5$, and $0.6 \mathrm{mM}$ of gibberellic acid and Bacillus subtilis respectively. 
(a)

Genotype BF1 APX

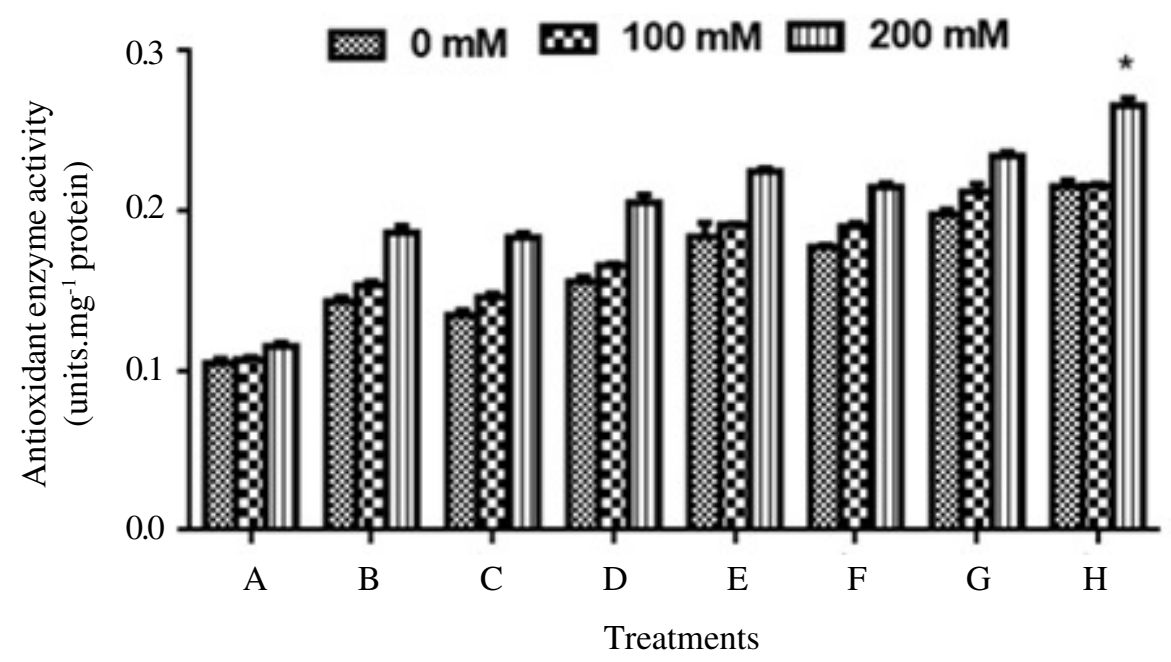

(b)

Genotype UC82B APX

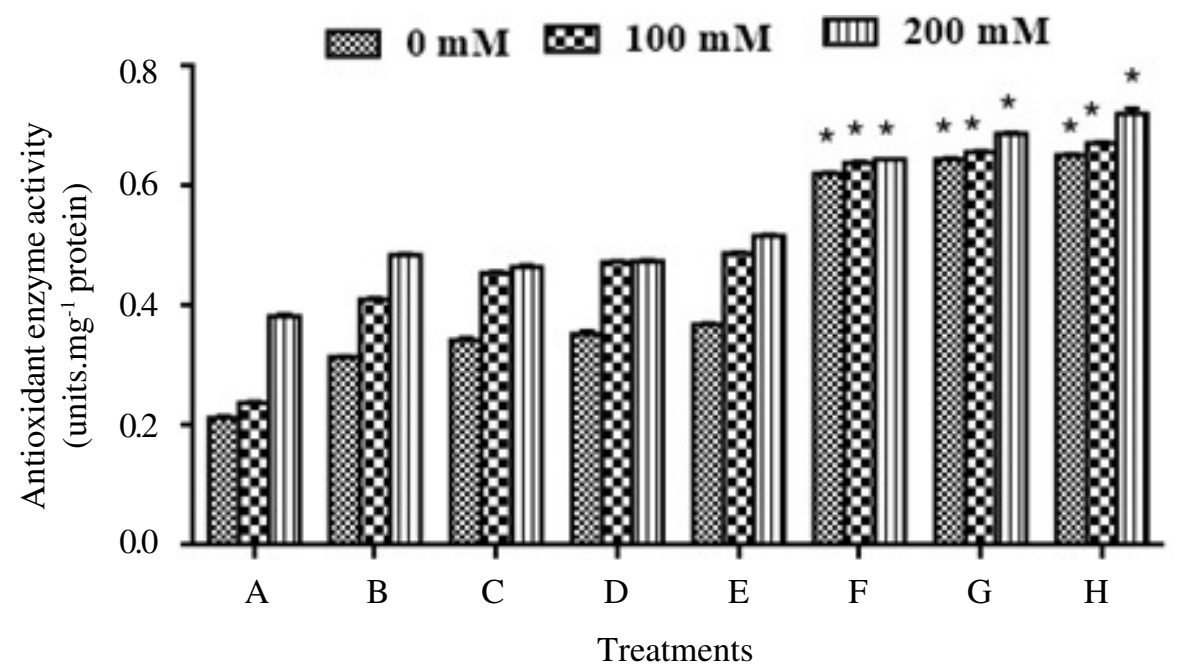

Figure 4. Ascorbate peroxide (APX) activity of salt-stressed tomato genotypes (a) BF1 and (b) UC82B under the influence of gibberellic acid and $B$. subtilis. Values represent means \pm standard error $(\mathrm{n}=3)$. *Significant difference $(\mathrm{P}<0.05)$ to the salt-stressed control and the normal control groups. Where A $=$ Controls (Normal control and Negative control groups), B, C, and D = 0.4, 0.5, and $0.6 \mathrm{mM}$ of gibberellic acid respectively, $\mathrm{E}=$ Bacillus subtilis, $\mathrm{F}, \mathrm{G}$, and $\mathrm{H}=0.4,0.5$, and $0.6 \mathrm{mM}$ of gibberellic acid and Bacillus subtilis respectively. 
(a) Genotype BF1 PP0

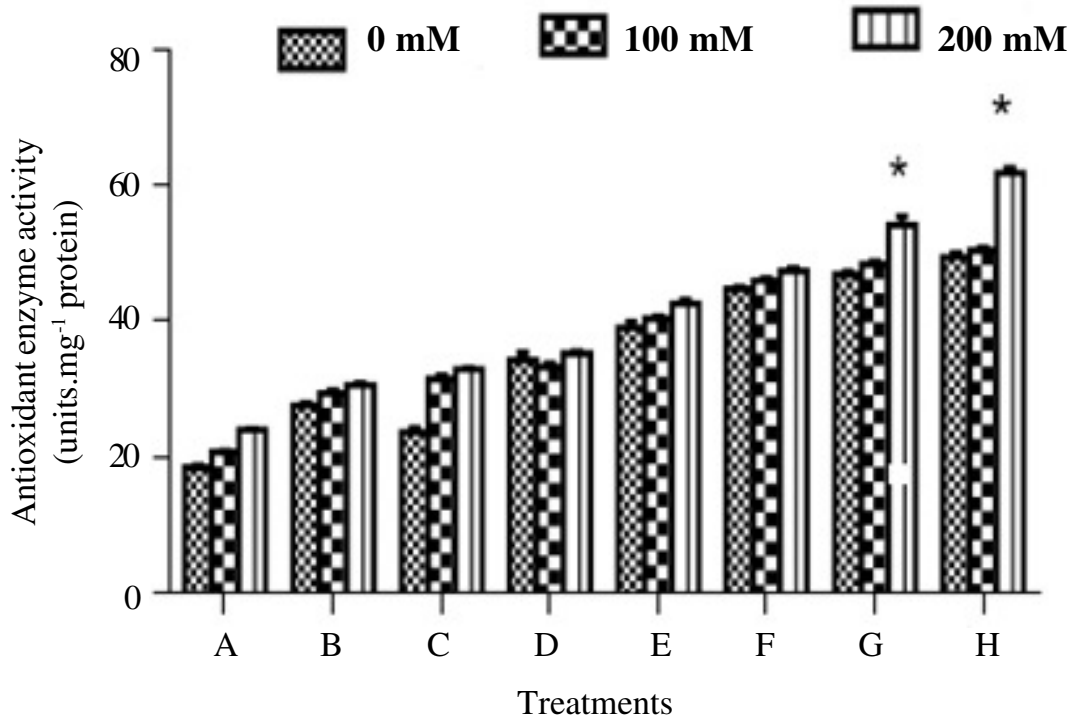

(b)

Genotype UC82 PP0

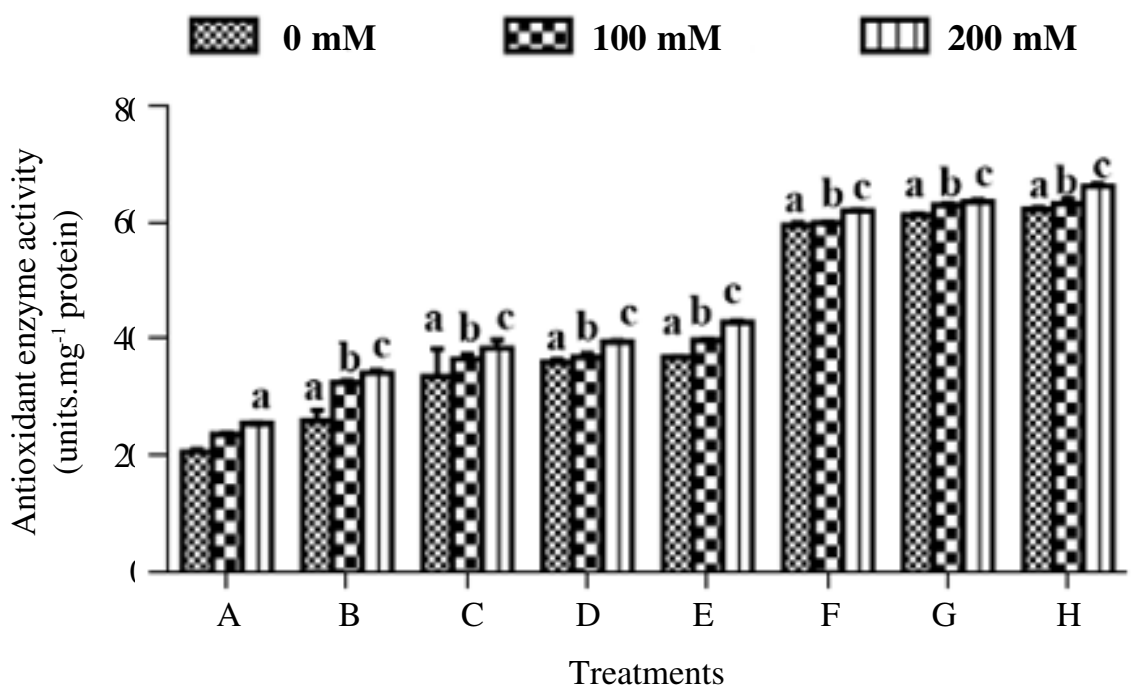

Figure 5. Polyphenol oxidase (PPO) activity of salt-stressed tomato genotypes (a) BF1 and (b) UC82B under the influence of gibberellic acid and B. subtilis. Values represent means \pm standard error $(\mathrm{n}=3)$. $*$ Significant difference $(\mathrm{P}<0.05)$ relatives to the salt-stressed control and the normal control groups. Where $\mathrm{A}=$ Controls (Normal control and Negative control groups), $\mathrm{B}, \mathrm{C}$, and $\mathrm{D}=0.4,0.5$, and $0.6 \mathrm{mM}$ of gibberellic acid respectively, $\mathrm{E}=$ Bacillus subtilis, $\mathrm{F}, \mathrm{G}$, and $\mathrm{H}=0.4,0.5$, and $0.6 \mathrm{mM}$ of gibberellic acid and Bacillus subtilis respectively. 
(a)

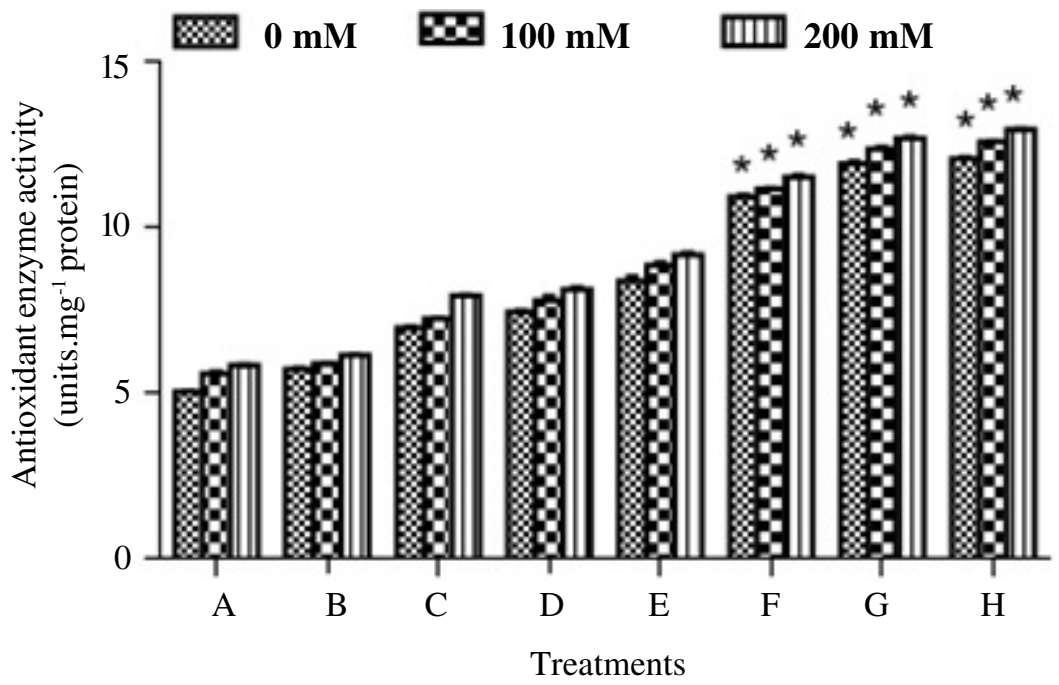

(b)

Genotype UC82B SOD

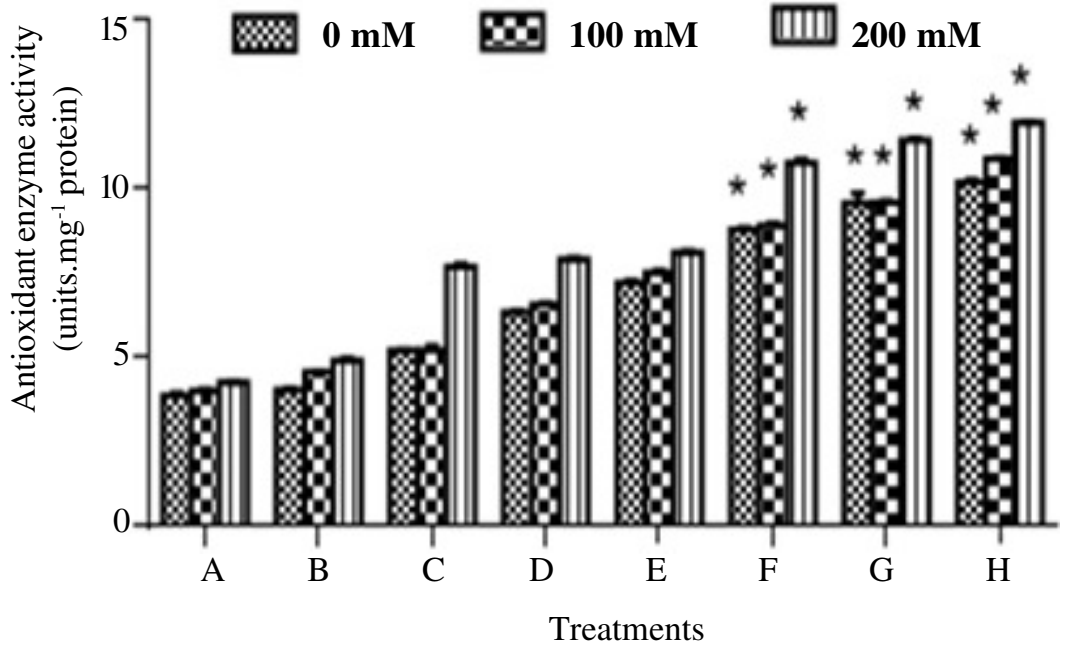

Figure 6. Superoxide dismutase (SOD) activity of salt-stressed tomato genotypes (a) BF1 and (b) UC82B under the influence of gibberellic acid and $B$. subtilis. Values represent means \pm standard error $(\mathrm{n}=3)$. *Significant difference $(\mathrm{P}<0.05)$ to the salt-stressed control and the normal control groups. Where $\mathrm{A}=$ Controls (Normal control and Negative control groups), B, C, and D = 0.4, 0.5, and $0.6 \mathrm{mM}$ of gibberellic acid respectively, $\mathrm{E}=$ Bacillus subtilis, $\mathrm{F}, \mathrm{G}$, and $\mathrm{H}=0.4,0.5$, and $0.6 \mathrm{mM}$ of gibberellic acid and Bacillus subtilis respectively. 
(a) Genotype BF1 Total flavonoids

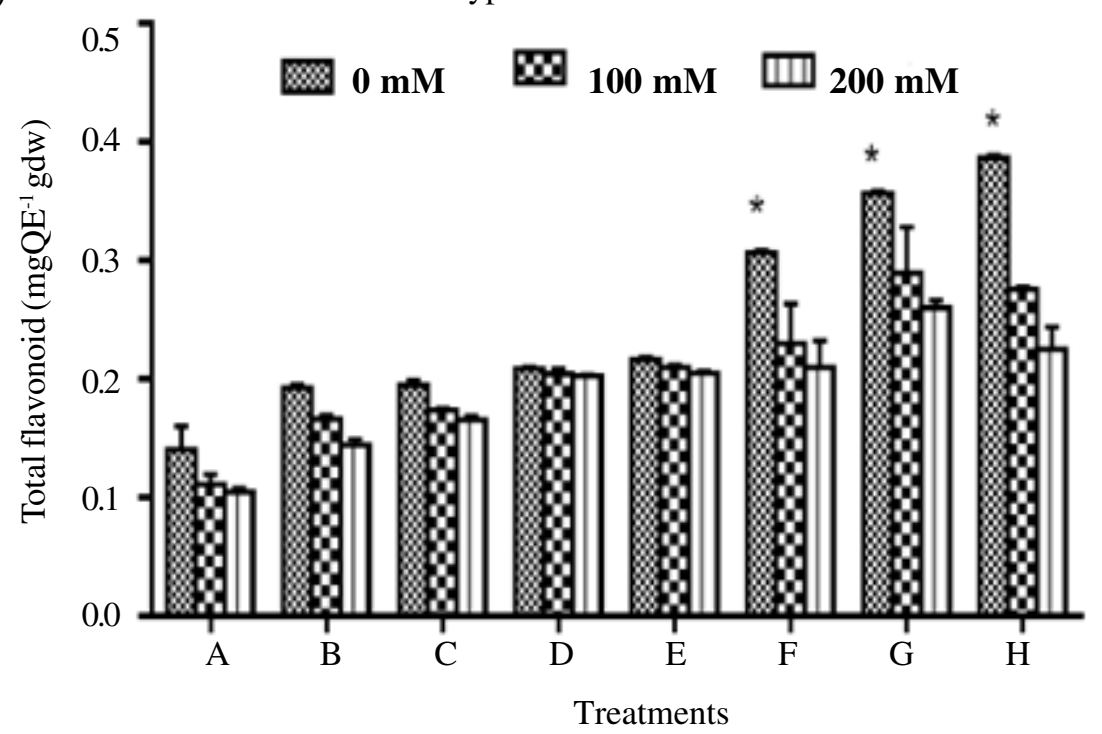

(b)

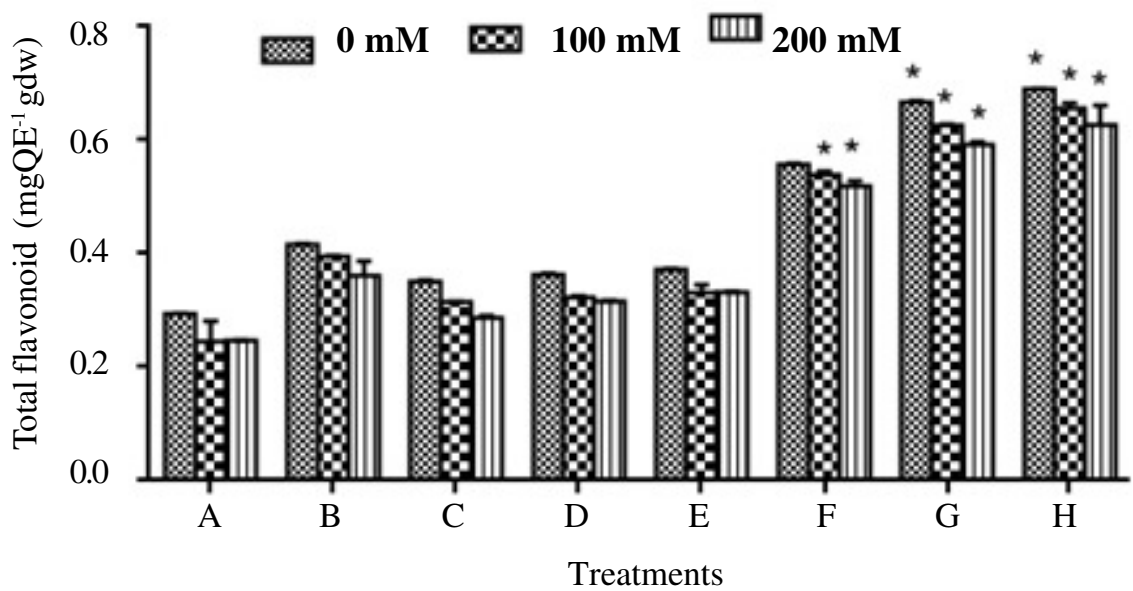

Figure 7. Total flavonoids content of salt-stressed tomato genotypes (a) BF1 and (b) UC82B under the influence of gibberellic acid and B. subtilis. Values represent means \pm standard error $(\mathrm{n}=3)$. *Significant difference $(\mathrm{P}<0.05)$ relatives to the salt-stressed control and the normal control groups. Where $\mathrm{A}=$ Controls (Normal control and Negative control groups), B, C, and D = 0.4, 0.5, and $0.6 \mathrm{mM}$ of gibberellic acid respectively, $\mathrm{E}=$ Bacillus subtilis, $\mathrm{F}, \mathrm{G}$, and $\mathrm{H}=0.4,0.5$, and $0.6 \mathrm{mM}$ of gibberellic acid and Bacillus subtilis respectively. 
(a) Genotype BF1 Total phenolic

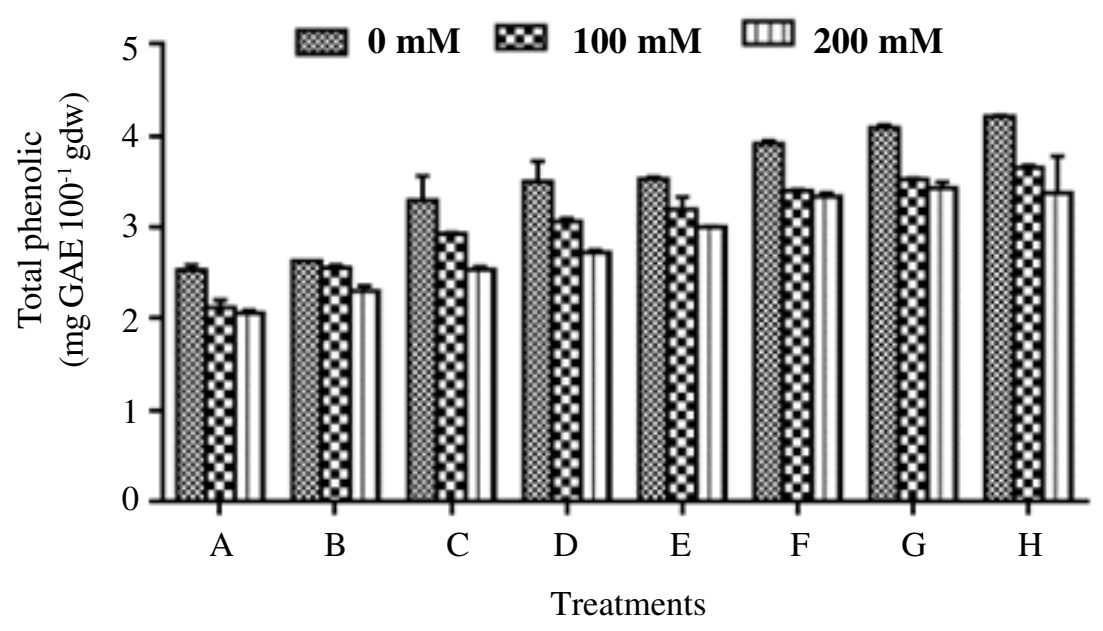

(b) Genotype UC82B Total phenolic

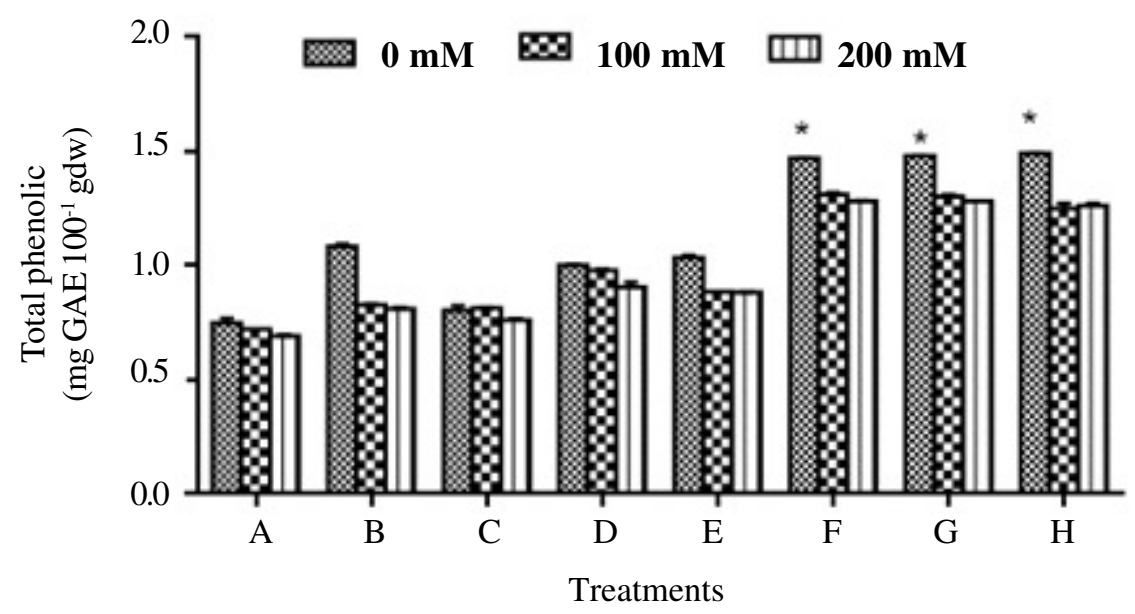

Figure 8. Total phenolic content of salt-stressed tomato genotypes (a) BF1 and (b) UC82B under the influence of gibberellic acid and B. subtilis. Values represent means \pm standard error $(n=3)$. *Significant difference $(\mathrm{P}<0.05)$ relatives to the salt-stressed control and the normal control groups. Where $\mathrm{A}=$ Controls (Normal control and Negative control groups), B, C, and D =0.4, 0.5, and 0.6 $\mathrm{mM}$ of gibberellic acid respectively, $\mathrm{E}=$ Bacillus subtilis, $\mathrm{F}, \mathrm{G}$, and $\mathrm{H}=0.4,0.5$, and $0.6 \mathrm{mM}$ of gibberellic acid and Bacillus subtilis respectively. 
increase in soluble protein content in faba bean plant growing under high-saline conditions.

The increased activity levels of superoxide dismutase (SOD), ascorbate peroxidase (APX), and polyphenol oxidase (PPO) in saltstressed tomato (BF1 and UC82B genotypes) under the combined effects of gibberellic acid and $B$. subtilis (Figs. 4,5, and 6) may be as a result of mechanisms of actions of both gibberellic acid and B. subtilis, that modulate reactive oxygen species through signal transduction. This corroborated with the findings of Mittova et al. (2003), who observed that plants defend themselves against reactive oxygen species by induction of activities of certain anti-oxidative enzymes such as catalase, peroxidase, glutathione reductase, and superoxide dismutase, with phytohormones application in respect to salt tolerance.

\section{CONCLUSION}

Pretreatment of tomato seeds with gibberellic acid $\left(\mathrm{GA}_{3}\right)$ and seedlings inoculation with $B$. subtilis individually or in combination contribute to salt stress tolerance in the two tomato $(\mathrm{BF} 1$ and UC82B) genotypes. This is evident with increase photosynthetic pigments, mineral concentrations, and enhance synthesis of proline, reducing sugar, soluble protein and modulation of antioxidant enzymes defense component and antioxidant potential of tomato plant. Gibberellic acid and B. subtilis reduce the effects of salinity stress on the two (BF1 and UC82B) genotypes of the tomato plant. Hence, they serve as alternatives, methods for averting food insecurity worldwide. Therefore, the antioxidative defence system in the saltstressed tomato genotypes improved by the synergistic effects of gibberellic acid and $B$. subtilis.

\section{ACKNOWLEDGEMENT}

We thank Pastor Odewale of the Department of Pharmaceutical Microbiology, University of
Ibadan, Nigeria for helping with the bacteria culture. The National Horticultural Research Institute, Ibadan, Nigeria generously supplied the seeds used in this study.

\section{REFERENCES}

Ahmad, P., Abdel Lateef, A.A., Hashem, A., Abd-Allah, E.F., Gucel, S. and Tran, L.S. P. 2016. Nitric oxide mitigates salt stress by regulating levels of osmolytes and antioxidant enzymes in chickpea. Frontiers in Plant Science 7:347-351

Al-Karaki, G.N. 2000. Growth of mycorrhizal tomato and mineral acquisition under salt stress. Mycorrhiza 10:51-54.

Alonso-Ramírez, A., Rodríguez, D., Reyes, D., Jiménez, A.J., Nicolás, G., López-Clement, M., Gómez-Cadenas, A. and Nicolás, C. 2009. Evidence for a role of gibberellins in salicylic acid-modulated early plant responses to abiotic stress in Arabidopsis seeds. Plant Physiology 150:1335-1344.

Amin, B., Mahleghah, G., Mahmood, H.M.R. and Hossein, M. 2009. Evaluation of the interaction effect of drought stress with ascorbate and salicylic acid on some of the physiological and biochemical parameters in okra (Hibiscus esculentus L.). Research Journal Biological Science 4:380-387.

AOAC. 2005. Association of Official Analytical Chemists. Official Methods of Analysis of the Association of Analytical Chemists International, 18th ed. Gaithersburg, MD U.S.A Official methods, 2005.08.

Bates, L.S., Waldern, R.P. and Teare, D. 1973. Rapid determination of free proline for water-stresss studies. Plant Soil 39:205207.

Chakraborti, N. and Mukherji, S. 2003. Effect of phytohormone pretreatment on nitrogen metabolism in Vigna radiata under salt stress. Biologia Plantarum 46:63-66.

Dernetriou, G., Neonaki, C., Navakoudis, E. and Kotzabasis, K. 2007. Salt stress impact on the molecular structure and function of the photosynthetic apparatus-The 
protective role of polyamines. Biochemistry Biophysics Acta 1767: 272-280.

Desingh, R. and Kanagaraj, G. 2007. Influence of salinity stress on photosynthesis and antioxidative systems in two cotton varities. Genetic Application of Plant Physiology 33:221-234.

Dodd, I.C. and Perez-Alfocea, F. 2012. Microbial amelioration of crop salinity stress. Journal Experimental Botany 63: 3415-3428.

Egamberdieva, D. 2012. Pseudomonas chlororaphis: A salt-tolerant bacterial inoculant for plant growth stimulation under saline soil conditions. Acta Physiology Plant 34: 751-756.

El-Shihaby, O.A., Alla, M.E., Younis, Z.M. and Bastawisy, E.L. 2002. Effect of kinetin on photosynthetic activity and carbohydrate content in waterlogged or seawater-treated Vigna sinensis and Zea mays plants. Plant Biosystems 136:277-290.

Esan, A.M., Masisi, K., Dada, F.A. and Olaiya, C.O. 2017. Comparative effects of indole acetic acid and salicylic acid on oxidative stress marker and antioxidant potential of okra (Abelmoschus esculentus) fruit under salinity stress. Scientia Horticulturae Journal 216:278-283.

FAOSTAT. 2019. FAOSTAT [database on the Internet]. Countries; elements production quantity; Items-tomatoes: Food and Agriculture Organization of the United Nations. Retrieved 9 August 2019.

Fan, R.Q, Yang, X. M, Xie, H.T. and Reeb, M. 2012. Determination of nutrients in hydroponic solutions using mid-infrared spectroscopy. Scientia Horticulturae Journal 144:48-54.

Hashem, A., Abd Allah, E.F., Alqarawi, A.A., Huqail Asma, A. and Egamberdieva, D. 2014. Alleviation of abiotic salt stress in Ochradenus baccatus (Del.) by Trichoderma hamatum (Bonord.) Bainier Journal of Plant Interaction 9(1):857-868.

Hussain, T., Koyro, H.W., Huchzermeyer, B. and Khan, M.A. 2015. Eco-physiological adaptations of Panicum antidote to hyperosmotic salinity: Water and ion relations and anti-oxidant feedback. Flora 212:30-37.

Katerji, N., van Hoorn, J. W., Hamdy, A. and Mastrorilli, M. 2003. Salinity effect on crop development and yield, analysis of salt tolerance according to several classifications methods. Agriculture Water Management 62:37-66.

Kim, D., Chun, Y., Kim, H. and Lee, C. 2003. Quantification of phenolic and their antioxidant capacity in fresh plums. Journal of Agriculture Food Chemistry 51:65096515.

Kumar, A., Dutt, S., Bagler, G., Ahuja, P.S. and Kumar, S. 2012. Engineering a thermostable superoxide dismutase functional at sub-zero to $>50^{\circ} \mathrm{C}$, which also tolerates autoclaving. Science Repository 2:387.

Lichtenthaler, H.K. and Wellburn, A.R. 1983. Determinations of total carotenoids and chlorophylls $\mathrm{a}$ and $\mathrm{b}$ of leaf extracts in different solvents. Biochemistry Society Trans 11:591-592.

Magan, J.J, Gallardo, M., Thompson, R.B. and Lorenzo, P. 2008. Effects of salinity on fruit yield and quality of tomato grown in soilless culture in greenhouses in Mediterranean climatic conditions. Agriculture Water Management 99:19-25.

Mahdi, Z., Orookhani, K. and Alizadeh, O. 2011. Effect of PGPR and AMF on the growth of two bread cultivars of tomato. Advances in Environmental Biology 5:2177-2181.

Mayak, S., Tirosh, T. and Glick, B.R. 2004. Plant growth-promoting bacteria confer resistance in tomato plants to salt stress. Plant Physiology Biochemistry 42:565572.

Metwali, E.M.R., Abdelmoneim, T.S., Mostafa, A. and BakheitNaif, M.S. 2015. Alleviation of salinity stress in faba bean (Vicia faba L.) plants by inoculation with plant growth promoting rhizobacteria (PGPR). Plant Omics Journal 8:449-460. 
Mittova, V., Ta, M., Volokita, M. and Guy, M. 2003. Upregulation of the leaf mitochondrial and peroxisomal antioxidative systems in response to salt-induced oxidative stress in the wild salt-tolerant tomato species Lycopersicon Pennell. Journal of Plant Cell Environment 26:845-856.

Mohamed, H.I. and Gomaa, E.Z. 2012. Effect of plant growth-promoting Bacillus subtilis and Pseudomonas fluorescens on growth and pigment composition of radish plants (Raphanus sativus) under $\mathrm{NaCl}$ stress. Photosynthetic 50:263-272.

Moxley, M.A., Tanner, J.J., and Becker, D.F. 2011. Steady-state Kinetic mechanism of the proline: ubiquinone oxidoreductase activity of proline utilization A (Put A) from Escherichia coli. Archives of Biochemistry Biophysics 516:113-120.

Oktay, M., Küfrevioçlu, I., Kocaçalýpkan, I. and Pakiroçlu, H. 1995. Polyphenol oxidase from Amasya apple. Journal of Food Science 60(3):494-496.

Park, Y.S., Jung, S.T., Kang, S.G., Heo, B.K., Arancibia-Avila, P., Toledo, F., Drzewiecki, J., Namiesnik, J. and Gorinstein, S. 2008. Antioxidants and proteins in ethylenetreated Kiwifruits. Food Chemistry 107:640-648.

Parviz, A., Satyawati, S. 2008. Salt stress phytochemical responses of plants. Plant Soil Environmental 54(3):89-99.

Pedranzani, H., Racagni, G., Alemano, S., Miersch, O., Ram’Irez, I., Pe Na-Cort'Es,
H., Taleisnik, E., Machado-Domenech, E. and Abdala, G. 2003. Salt tolerant tomato plants show increased levels of jasmonic acid. Plant Growth Regulation 41:149158.

Saleh, S.A., Heuberger, H. and Schnitzler, W. H. 2005. Alleviation of salinity effects on artichoke productivity by Bacillus subtilis FZB24, supplemental $\mathrm{Ca}$ and micronutrients. Journal of Applied Botany Food Quality-Angewandre Botanik 79: 2432.

Tejera, G.NA., Olivera, M., Iribarne, C. and Lluch, C. 2004. Partial purification and characterization of a non-specific acid phosphatase in leaves and root nodules of Phaseolus vulgaris. Plant Physiology and Biochemistry 42:58-5591.

Tester, M. 2003. $\mathrm{Na}^{+}$tolerance and $\mathrm{Na}+$ transport in higher plants. Annal of Botany 91:503-527.

Turan, M., Ekinci, M., Yildirim, E., Gne ${ }^{\mathrm{o}}$, A., Karagz, K., Kotan, R. and Dursun, A. 2014. Plant growth-promoting rhizobacteria improved growth, nutrient, and hormone content of cabbage (Brassica oleracea) seedlings Turkish Journal of Agriculture 38:327-333.

Yoshimura, K., Yabuta, Y., Ishikawa, T. and Shigeoka, S. 2000. Expression of spinach ascorbate peroxidase isoenzymes in response to oxidative stresses. Plant Physiology Journal 123:223-234. 